\title{
BMJ
}

\section{Pharmacological and lifestyle interventions to prevent or delay type 2 diabetes in people with impaired glucose tolerance: systematic review and meta-analysis}

\author{
Clare L Gillies, medical statistician', Keith R Abrams, professor of medical statistics ${ }^{1}$, Paul C \\ Lambert, senior lecturer in medical statistics', Nicola J Cooper, MRC senior training fellow in health \\ services research', Alex I Sutton, reader in medical statistics ${ }^{1}$, Ron T Hsu, clinical senior teaching fellow in \\ epidemiology and public health', Kamlesh Khunti, clinical senior lecturer ${ }^{2}$
}

${ }^{1}$ Centre for Biostatistics and Genetic Epidemiology, Department of Health Sciences, University of Leicester, Leicester LE1 7RH

${ }^{2}$ Clinical Division of General Practice and Primary Health Care, Department of Health Sciences, University of Leicester

Correspondence to:

CLGillies clg13@le.ac.uk

doi: 10.1136/bmj.39063.689375.55

\section{ABSTRACT}

Objective To quantify the effectiveness of pharmacological and lifestyle interventions to prevent or delay type 2 diabetes in people with impaired glucose tolerance.

Data sources Medline, Embase, and the Cochrane library searched up to July 2006. Expert opinions sought and reference lists of identified studies and any relevant published reviews checked.

Study selection Randomised controlled trials that evaluated interventions to delay or prevent type 2 diabetes in individuals with impaired glucose tolerance. Results 21 trials met the inclusion criteria, of which 17 , with 8084 participants with impaired glucose tolerance, reported results in enough detail for inclusion in the metaanalyses. From the meta-analyses the pooled hazard ratios were 0.51 ( $95 \%$ confidence interval 0.44 to 0.60 ) for lifestyle interventions $v$ standard advice, 0.70 (0.62 to 0.79 ) for oral diabetes drugs $v$ control, 0.44 (0.28 to 0.69 ) for orlistat $v$ control, and 0.32 (0.03 to 3.07) for the herbal remedy jiangtang bushen recipe $v$ standard diabetes advice. These correspond to numbers needed to treat for benefit (NNTB) and harm (NNTH) of 6.4 for lifestyle (95\% credible interval, NNTB 5.0 to NNTB 8.4), 10.8 for oral diabetes drugs (NNTB 8.1 to NNTB 15.0), 5.4 for orlistat (NNTB 4.1 to NNTB 7.6), and 4.0 for jiangtang bushen (NNTH 16.9 to NNTB 24.8).

Conclusions Lifestyle and pharmacological interventions reduce the rate of progression to type 2 diabetes in people with impaired glucose tolerance. Lifestyle interventions seem to be at least as effective as drug treatment.

\section{INTRODUCTION}

Type 2 diabetes is a growing health problem, with the prevalence of the disease set to rise dramatically in Westernised societies. Individuals with diabetes have a life expectancy that can be shortened by as much as 15 years, with up to $75 \%$ dying of macrovascular complications. ${ }^{1}$ In England around 1.3 million people are currently diagnosed with diabetes and incidence is increasing in all age groups. ${ }^{2}$ Around 5\% of total NHS resources and up to $10 \%$ of hospital inpatient resources is used for the care of people with diabetes. ${ }^{2}$ Interventions to delay or even prevent type 2 diabetes have the potential to improve the health of a population and reduce the burden of healthcare costs.

People with impaired glucose tolerance have a high risk of developing type 2 diabetes, ${ }^{3}$ and consequently many trials of interventions for prevention of type 2 diabetes have focused on such individuals. Interventions assessed have been diverse and include pharmacological, lifestyle, and herbal remedies.

Several current reviews have been carried out on prevention of type 2 diabetes, ${ }^{14-9}$ covering different aspects such as pharmacological interventions or the effects of weight loss. We consolidated the evidence by considering all forms of intervention in a systematic review and undertook a meta-analysis.

\section{METHODS}

Searching

We searched Medline (1966 to July 2006) and Embase (1980 to July 2006) with search strategies developed by combining phase 1 and 2 of the Cochrane Collaboration's randomised controlled trials filter, ${ }^{10}$ search terms covering both type 2 diabetes and prevention, and clinical terms for impaired glucose tolerance. We also searched the Cochrane central register of controlled trials and the Cochrane library of systematic reviews (issue 2, 2006), sought expert opinion on relevant trials, and checked references of any articles that met the inclusion criteria and published reviews that considered prevention of type 2 diabetes.

\section{Selection}

Study selection was restricted to randomised controlled trials to ensure the inclusion of only high quality evidence. Studies had to have an intervention to delay or prevent type 2 diabetes in a sample or subsample of individuals with impaired glucose tolerance. Development of diabetes was a required outcome measure. Three of the authors (CLG, KRA, PCL) determined trial inclusion by consensus. At least one of the 


\section{Table 1 | Characteristics of studies on lifestyle interventions included in review}

\begin{tabular}{|c|c|c|c|}
\hline Trial & Population & Interventions & $\begin{array}{l}\text { Definitions of impaired glucose } \\
\text { tolerance and type } 2 \text { diabetes }\end{array}$ \\
\hline Pan, China (1997) ${ }^{\mathrm{w} 22}$ & $\begin{array}{l}\mathrm{n}=530 \text { Chinese with impaired } \\
\text { glucose tolerance. All }>25 \text { years, } 283 \\
\text { men, } 247 \text { women }\end{array}$ & $\begin{array}{l}\text { Diet group received individual and group counselling sessions, those with BMI >25 } \\
\text { encouraged to lose weight. Exercise group encouraged to increase their daily } \\
\text { exercise. Diet and exercise group received both interventions as above. Control } \\
\text { group received routine advice }\end{array}$ & WHO 1985 criteria \\
\hline $\begin{array}{l}\text { Diabetes Prevention Study } \\
\text { (DPS), Finland }(2003)^{25}\end{array}$ & $\begin{array}{l}\mathrm{n}=522 \text {, overweight with impaired } \\
\text { glucose tolerance, } 67 \% \text { women }\end{array}$ & $\begin{array}{l}\text { Control group received limited advice on diet and exercise; intervention group given } \\
\text { tailored, detailed advice on diet, weight reduction, and exercise }\end{array}$ & WHO 1985 criteria \\
\hline JDPP, Japan (2005) ${ }^{w 18}$ & $\begin{array}{l}\mathrm{n}=240 \text { with impaired glucose } \\
\text { tolerance, } 49 \% \text { women, mean age } \\
51 \text {, mean } \mathrm{BMI} 25\end{array}$ & $\begin{array}{l}\text { Control group received standard diet and exercise advice. Intervention group } \\
\text { encouraged to lose weight if necessary, walk for } 700 \mathrm{kcals} \text { worth/week, and change } \\
\text { their diet with help of dietician }\end{array}$ & WHO 1999 criteria \\
\hline Kosaka, Japan (2005) ${ }^{\text {w27 }}$ & $\begin{array}{l}\mathrm{n}=356 \text { men with impaired glucose } \\
\text { tolerance, aged } 30-70\end{array}$ & $\begin{array}{l}\text { Control group advised to lose weight if } \mathrm{BMI} \geq 24 \text { and intervention group if } \mathrm{BMI} \geq 22 \text { by } \\
\text { eating smaller meals and increasing physical activity. Advice repeated every } 6 \\
\text { months for controls and } 3-4 \text { months for intervention group }\end{array}$ & WHO criteria in 1980 \\
\hline Liao, USA (2002) ${ }^{\mathrm{w} 29}$ & $\begin{array}{l}\mathrm{n}=70 \text { Japanese Americans with } \\
\text { impaired glucose tolerance, } 55 \% \\
\text { female }\end{array}$ & $\begin{array}{l}\text { Intervention group put on the American Heart Association step } 2 \text { diet, plus } 1 \mathrm{hr} \\
\text { endurance exercise three times/week. Control group recommended less intensive } \\
\text { step } 1 \text { diet and stretching exercises three times/week }\end{array}$ & WHO criteria in 1998 \\
\hline Tao, China (2004) & $\begin{array}{l}\mathrm{n}=60 \text { with impaired glucose } \\
\text { tolerance, } 43 \% \text { female, aged } 34-65 \text {, } \\
\text { mean age } 51\end{array}$ & $\begin{array}{l}\text { Both groups received dietary advice. Intervention group also received regular } \\
\text { moderately intensive exercise training }\end{array}$ & WHO 1999 criteria \\
\hline Wein, Australia (1999) ${ }^{\text {w35 }}$ & $\begin{array}{l}n=200 \text { women with previous } \\
\text { gestational diabetes and currently } \\
\text { with impaired glucose tolerance }\end{array}$ & $\begin{array}{l}\text { Intervention group received advice on intensive dietary modification, control group } \\
\text { given routine advice }\end{array}$ & WHO 1985 criteria \\
\hline
\end{tabular}

$\mathrm{BMI}=$ body mass index.

\begin{tabular}{|c|c|c|c|}
\hline Trial & Population & Interventions & $\begin{array}{l}\text { Definitions of impaired glucose } \\
\text { tolerance and type } 2 \text { diabetes }\end{array}$ \\
\hline EDIT, UK $(2003)^{\mathrm{w} 3}$ & $\begin{array}{l}n=631 \text {, some with impaired glucose tolerance, } 49 \% \\
\text { men, } 94 \% \text { white }\end{array}$ & $\begin{array}{l}\text { Factorial trial. Subjects randomised to acarbose }(50 \mathrm{mg} \\
\text { three time/day) or placebo and metformin ( } 500 \mathrm{mg} \\
\text { three times/day) or placebo }\end{array}$ & WHO 1985 criteria \\
\hline Eriksson, Finland (2006) ${ }^{\text {w38 }}$ & $\begin{array}{l}\mathrm{n}=34 \text { with impaired glucose tolerance and first degree } \\
\text { relative with type } 2 \text { diabetes. Age } 35-70 \text {, BMI } 25-35 \text {, } \\
74 \% \text { women }\end{array}$ & Randomised to placebo or $2.5 \mathrm{mg}$ glipizide daily & WHO criteria in 2006 \\
\hline Fan, China $(2004)^{\text {w20 }}$ & $\mathrm{n}=51$ with impaired glucose tolerance, age $>35, \mathrm{BMI}>19$ & $\begin{array}{l}\text { All received standard diet and exercise advice. } \\
\text { Intervention group additionally took jiangtang bushen } \\
\text { recipe } 2-3 \text { times/week }\end{array}$ & WHO 1999 criteria \\
\hline $\begin{array}{l}\text { Heymsfield, USA and Europe ( } \\
2000)^{\text {w28 }}\end{array}$ & $\begin{array}{l}\mathrm{n}=675 \text { obese adults ( } 120 \text { with impaired glucose } \\
\text { tolerance), BMI } 30-43\end{array}$ & $\begin{array}{l}\text { All recommended low energy diet then randomised to } \\
\text { placebo or } 120 \mathrm{mg} \text { orlistat, three times/day }\end{array}$ & WHO 1985 criteria \\
\hline Li, China $(1999)^{\text {w30 }}$ & $\mathrm{n}=90$ with impaired glucose tolerance, aged $30-60$ & $\begin{array}{l}250 \mathrm{mg} \text { metformin or placebo three times/day for } 12 \\
\text { months }\end{array}$ & WHO 1985 criteria \\
\hline Pan, China $(2003)^{49}$ & $\begin{array}{l}n=261 \text { with impaired glucose tolerance, aged } 35-70 \text {, } \\
B M I>19 \text { and } \leq 34,60 \% \text { women }\end{array}$ & $50 \mathrm{mg}$ acarbose or placebo three times/day & $\begin{array}{l}\text { American Diabetes Association } \\
\text { (ADA) } 1997 \text { criteria }\end{array}$ \\
\hline $\begin{array}{l}\text { STOP-NIDDM, Canada, Germany, } \\
\text { Austria, Norway, Denmark, Sweden, } \\
\text { Finland, Israel and Spain }(2002)^{\text {w33 }}\end{array}$ & $\begin{array}{l}n=1429, \text { with impaired glucose tolerance, age } 40-70 \text {, } \\
B M I ~ 25-40\end{array}$ & $100 \mathrm{mg}$ acarbose or placebo three times/day & WHO 1985 criteria \\
\hline TRIPOD, USA (2002)w34 & $\begin{array}{l}\mathrm{n}=266 \text { insulin resistant ( } 167 \text { with impaired glucose } \\
\text { tolerance), Hispanic women with previous gestational } \\
\text { diabetes }\end{array}$ & $\begin{array}{l}400 \mathrm{mg} \text { troglitazone or placebo once a day, all received } \\
\text { standard diet and exercise }\end{array}$ & $\begin{array}{l}\text { Impaired glucose tolerance } \\
\text { diagnosed if sum of } 5 \text { OGTT } \\
\geq 34.7 \mathrm{mmol} / \mathrm{l} \text {. Diabetes defined } \\
\text { by ADA } 1997 \text { criteria }\end{array}$ \\
\hline XENDOS, Sweden (2004) w33 & $\begin{array}{l}n=3277 ; 694 \text { had impaired glucose tolerance, age } 30 \text { - } \\
60, \text { minimum BMI } 30\end{array}$ & $\begin{array}{l}120 \mathrm{mg} \text { orlistat or placebo three times/day, all patients } \\
\text { prescribed low calorie diet and exercise }\end{array}$ & WHO 1994 \\
\hline
\end{tabular}

$\mathrm{BMI}=$ body mass index; OGT=oral glucose tolerance test.

prescribed low calorie diet and exercise

research team with a translator assessed foreign language papers with relevant titles or English abstracts. All translators were familiar with medical literature and terminology.

\section{Validity assessment}

Two authors (CLG, KRA) independently assessed all studies included in the meta-analyses for quality, using both the Jadad score ${ }^{11}$ and, as it is an important aspect of quality not included in the Jadad score, concealment of allocation.

\section{Data abstraction}

Two authors (CLG, KK) independently extracted data on progression to type 2 diabetes, body mass index, and age and resolved disagreements through discussion.

Meta-analyses were conducted on the log hazard ratio scale. Not all the trials reported the necessary statistics directly so we had to transform and estimate the reported data as necessary (see bmj.com). ${ }^{12}{ }^{13}$ In some cases we could estimate only incidence rate ratios. Incidence rate ratios can be considered approximations of 


\begin{tabular}{|c|c|c|c|}
\hline Trial & Population & Interventions & $\begin{array}{c}\text { Definitions of impaired glucose tolerance and type } 2 \\
\text { diabetes }\end{array}$ \\
\hline $\begin{array}{l}\text { Diabetes prevention } \\
\text { programme (DPP), USA } \\
(2002)^{\text {w1 w23 }}\end{array}$ & $\begin{array}{l}\mathrm{n}=3234 \text { with impaired } \\
\text { glucose tolerance, aged } \\
\geq 25 . \text { Minimum BMI } 24 \text { ( } 22 \\
\text { in Asians), } 32.3 \% \text { men, } \\
54.7 \% \text { white }\end{array}$ & $\begin{array}{l}\text { Four interventions: standard lifestyle recommendations plus placebo, } \\
\text { standard lifestyle recommendations plus metformin ( } 850 \mathrm{mg} \text { twice daily), } \\
\text { standard lifestyle recommendations plus troglitazone ( } 400 \mathrm{mg} \text { daily) and } \\
\text { an intensive programme of lifestyle modification. Troglitazone arm } \\
\text { discontinued early because of safety reasons }\end{array}$ & ADA 1997 criteria \\
\hline Fang, China $(2004)^{\text {w19 }}$ & $\begin{array}{l}\mathrm{n}=178 \text { with impaired } \\
\text { glucose tolerance, } 55 \% \\
\text { men }\end{array}$ & $\begin{array}{l}\text { Four interventions: standard prevention education, education and } \\
\text { monitoring of diet and exercise, acarbose } 25-50 \mathrm{mg} 3 \text { times/day, or } \\
\text { flumamine } 125-250 \mathrm{mg} 3 \text { times/day }\end{array}$ & WHO 1985 criteria \\
\hline $\begin{array}{l}\text { Indian diabetes prevention } \\
\text { programme (IDDP), India ( } \\
2006)^{\text {w39 }}\end{array}$ & $\begin{array}{l}\mathrm{n}=531 \text { native Asian } \\
\text { Indians with impaired } \\
\text { glucose tolerance, aged } \\
35-55,21 \% \text { women }\end{array}$ & $\begin{array}{l}\text { Four interventions: standard lifestyle advice, lifestyle modification, } \\
\text { metformin ( } 500 \mathrm{mg} \text { twice daily, dropping to } 250 \mathrm{mg} \text { twice daily after } \\
\text { median of } 40 \text { days), combination of lifestyle modification and metformin }\end{array}$ & WHO 1999 criteria \\
\hline Jarrett, UK (1979) ${ }^{\mathrm{w} 2}$ & $\begin{array}{l}\mathrm{n}=204 \text { men with impaired } \\
\text { glucose tolerance }\end{array}$ & $\begin{array}{l}\text { Factorial trial: } 50 \mathrm{mg} \text { phenformin daily or placebo and recommendation to } \\
\text { limit carbohydrate intake to } 120 \mathrm{~g} \text { /day or just to limit sucrose (table sugar) }\end{array}$ & $\begin{array}{l}\text { Survey blood glucose } 6.1-11.0 \mathrm{mmol} / \mathrm{l} \text { and OGTT peak } \\
\text { blood glucose } \geq 10 \mathrm{mmol} / \mathrm{l} \text { and } 2 \mathrm{hr} \text { blood glucose } 6.7 \text { - } \\
11.0 \mathrm{mmol} / \mathrm{l} \text {; or } 2 \text { values }>10 \mathrm{mmol} / \mathrm{l} \text {; or peak blood } \\
\text { glucose } \geq 10.0 \text { and mean } 2 \mathrm{hr} \text { glucose } \geq 6.7 \text {. Two } \\
\text { successive } 2 \text { hour post glucose blood glucose } \\
\text { concentrations }>11.1 ; 3 \text { non-successive } 2 \text { hr tests }>11.1 \text {; } \\
\text { development of symptoms and raised glucose }\end{array}$ \\
\hline Keen, UK (1982) ${ }^{\mathrm{w} 36}$ & $\begin{array}{l}\mathrm{n}=241 \text { with impaired } \\
\text { glucose tolerance }\end{array}$ & $\begin{array}{l}\text { Factorial trial: tolbutamide ( } 0.5 \mathrm{~g} \text { twice daily) or placebo and either dietary } \\
\text { teaching to restrict carbohydrate intake to } 120 \mathrm{~g} / \text { day or advice to restrict } \\
\text { table sugar }\end{array}$ & $\begin{array}{l}\text { Blood glucose } 6.7-11.1 \mathrm{mmol} / \mathrm{l} 2 \text { hours after oral } \\
\text { glucose load of } 50 \mathrm{~g} \text {. Two hour post load glucose } \\
>11.1 \mathrm{mmol} / \mathrm{l}\end{array}$ \\
\hline
\end{tabular}
$>11.1 \mathrm{mmol} / \mathrm{l}$

hazard ratios, although both are modelled under different assumptions. ${ }^{13}$ When insufficient data had been published, we contacted study authors if possible.

Interventions were either lifestyle, comprising diet and exercise interventions, or pharmacological and herbal, comprising oral diabetes drugs, the anti-obesity drug orlistat, and jiangtang bushen recipe, a Chinese herbal remedy.

\section{Quantitative data synthesis}

We fitted random effects meta-analyses models ${ }^{14}$ to allow for heterogeneity between studies (see table 4). We used the pooled hazard ratios from the meta-analyses, together with the pooled hazards of developing type 2 diabetes from the control arms of the trials, under the assumption of a constant hazard, to estimate the difference the intervention would make in the five year cumulative incidence of developing diabetes and the associated number need to treat.

We did not include troglitazone in the meta-analyses as it has been withdrawn from several markets worldwide because of problems of liver toxicity, ${ }^{\mathrm{w} 1}$ though we have discussed trial results in the review for interest. The trial by Jarrett et al used a factorial design, assessing one pharmacological and one lifestyle intervention. $^{\text {w2 }}$ In our analysis we assumed the two interventions did not interact.

Further analyses, as described below, were conducted separately for lifestyle interventions, oral diabetes drugs, orlistat, and jiangtang bushen, although not all analyses could be carried out for the last two categories because of the small number of trials. We quantified heterogeneity between studies with the $I^{2}$ statistic $^{15}$ and explored it through metaregression models, ${ }^{14}$ assessing mean age, mean body mass index, and length of follow-up individually (see table 2). Because of heterogeneity in the trial populations, the underlying rate of development of type 2 diabetes varied between trials. We assessed the effect of this baseline risk on effectiveness of interventions by fitting a bayesian meta-analysis model, accounting for both the uncertainty in the baseline risk and the inherent correlation between the baseline risk and hazard ratios. ${ }^{16}$ Impact of study quality was considered with the overall Jadad score and each component separately. We used a cumulative analysis approach by meta-analysing all the highest scoring studies, followed by inclusion of those that scored one point less, continuing until all studies were included. We then compared the pooled effect sizes at each step. Concealment of allocation was assessed by removing the trials that had reported this from the meta-analyses.

We undertook sensitivity analyses to assess the effect of different definitions of impaired glucose tolerance and type 2 diabetes used by different trials by removing the studies using the newer, lower threshold for fasting plasma glucose from the meta-analyses. To investigate the influence of an individual study on the hazard ratio, we examined the effect of removing each study individually from the meta-analyses. Publication bias was assessed with Begg's and Egger's tests. ${ }^{14}$ All analyses were carried out in Stata (StataCorp, College Station, TX) apart from the baseline risk and number needed to treat models, which were fitted in WinBUGS. ${ }^{17}$

\section{RESULTS}

Trial flow

We identified 11383 articles by the Medline and Embase searches (fig 1). We assessed the titles and abstracts and obtained the full articles for any that were potentially relevant (see web reference list on bmj.com). Of these, 27 were in English, and they 
Table 4 | Information used for the meta-analyses of interventions to prevent or delay type 2 diabetes

\begin{tabular}{|c|c|c|c|c|c|c|c|c|c|c|c|}
\hline \multirow[t]{2}{*}{ Trial } & \multirow{2}{*}{ Intervention } & \multirow{2}{*}{$\begin{array}{l}\text { Log hazard } \\
\text { ratio (SE)* }\end{array}$} & \multirow{2}{*}{$\begin{array}{c}\text { Mean BMI } \\
\left(\mathrm{kg} / \mathrm{m}^{2}\right)\end{array}$} & \multirow{2}{*}{$\begin{array}{c}\text { Mean } \\
\text { age } \\
\text { (years) }\end{array}$} & \multirow{2}{*}{$\begin{array}{c}\text { Average } \\
\text { follow-up } \\
\text { (years) }\end{array}$} & \multirow{2}{*}{$\begin{array}{c}\text { Baseline } \\
\text { risk† }\end{array}$} & \multicolumn{5}{|c|}{ Quality assessment $\ddagger$} \\
\hline & & & & & & & $\begin{array}{l}\text { Concealed } \\
\text { allocation }\end{array}$ & Randomisation & Blinding & $\begin{array}{l}\text { Withdrawals } \\
\text { and } \\
\text { dropouts }\end{array}$ & Jadad score \\
\hline
\end{tabular}

Lifestyle

\begin{tabular}{|c|c|c|c|c|c|c|c|c|c|c|c|}
\hline Da Qing, $1997^{\text {w22 }}$ & Diet & $-0.45(0.22)$ & 25.8 & 45.6 & $4.51^{\star}$ & 15.7 & No & 1 & 0 & 1 & 2 \\
\hline Jarrett, $1979^{\mathrm{w} 2}$ & Diet & $-0.17(0.39)$ & 26.2 & 56.7 & $4.39^{\star}$ & 2.6 & No & 1 & 0 & 1 & 2 \\
\hline Wein, 1999w35 & Diet & $-0.46(0.30)$ & 25.4 & 38.7 & 4.25 & 7.1 & No & 1 & 0 & 1 & 2 \\
\hline Da Qing, 1997w22 & Exercise & $-0.64(0.23)$ & 25.8 & 45.3 & $4.62^{\star}$ & 15.7 & No & 1 & 0 & 1 & 2 \\
\hline Tao, $2004^{\mathrm{w} 21}$ & Both & $-1.20(0.57)$ & 25.4 & 51.0 & 2.58 & 17.0 & No & 1 & 0 & 1 & 2 \\
\hline Da Qing, $1997^{\mathrm{w} 22}$ & Both & $-0.49(0.23)$ & 26.3 & 45.5 & $4.52^{\star}$ & 15.7 & No & 1 & 0 & 1 & 2 \\
\hline DPP, $2002^{\mathrm{w} 23}$ & Both & $-0.87(0.11)$ & 34.0 & 50.4 & 2.80 & 11.0 & No & 1 & 0 & 0 & 1 \\
\hline DPS, $2003^{\mathrm{w} 25}$ & Both & $-0.92(0.22)$ & 31.2 & 55.0 & 3.20 & 7.4 & No & 1 & 0 & 0 & 1 \\
\hline Fang, $2004^{\mathrm{w} 19}$ & Both & $-0.29(0.39)$ & 25.0 & 48.0 & $3.88^{\star}$ & 10.0 & No & 2 & 0 & 1 & 3 \\
\hline IDDP, 2006"w39 & Both & $-0.47(0.20)$ & 25.8 & 45.9 & 2.50 & 18.3 & No & 1 & 0 & 1 & 2 \\
\hline Kosaka, $2005^{\text {w27 }}$ & Both & $-1.24(0.60)$ & 23.8 & $51.5^{*}$ & 3.64 & 2.6 & No & 1 & 0 & 1 & 2 \\
\hline Liao, $2002^{\text {w29 }}$ & Both & $-0.66(1.22)$ & 26.1 & 54.0 & $1.83^{\star}$ & 3.1 & No & 1 & 0 & 1 & 2 \\
\hline
\end{tabular}

Pharmacological/herbal

\begin{tabular}{|c|c|c|c|c|c|c|c|c|c|c|c|}
\hline Fang, $2004^{\mathrm{w} 19}$ & Acarbose & $-1.31(0.55)$ & 24.8 & 48.7 & $4.14^{\star}$ & 10.0 & No & 2 & 0 & 1 & 3 \\
\hline Pan, $2003^{\text {w31 }}$ & Acarbose & $-0.51(0.48)$ & 25.7 & 54.5 & 0.37 & 30.0 & No & 1 & 2 & 0 & 3 \\
\hline $\begin{array}{l}\text { STOP-NIDDM, } \\
2002^{\text {w33 }}\end{array}$ & Acarbose & $-0.29(0.09)$ & 30.9 & 54.5 & 3.30 & 12.6 & Yes & 2 & 0 & 1 & 3 \\
\hline Fang, $2004^{\mathrm{w} 19}$ & Flumamine & $-0.84(0.49)$ & 25.0 & 48.7 & $4.06^{\star}$ & 10.0 & No & 2 & 0 & 1 & 3 \\
\hline Eriksson, $2006^{\text {w38 }}$ & Glipizide & $-1.74(1.10)$ & 28.1 & 56.5 . & 1.32 & 23.8 & No & 1 & 2 & 1 & 4 \\
\hline DPP, $2002^{\text {w23 }}$ & Metformin & $-0.37(0.10)$ & 34.0 & 50.6 & 2.80 & 11.0 & No & 1 & 1 & 0 & 2 \\
\hline IDDP, $2006^{\mathrm{w} 39}$ & Metformin & $-0.43(0.20)$ & 25.8 & 45.9 & 2.50 & 18.3 & No & 1 & 0 & 1 & 2 \\
\hline $\mathrm{Li}, 1999^{\text {w30 }}$ & Metformin & $-0.72(0.71)$ & 26.2 & 49.5 & 0.92 & 7.1 & No & 1 & 1 & 1 & 3 \\
\hline Jarrett, $1979^{\mathrm{w} 2}$ & Phenformin & $0.01(0.39)$ & 26.2 & 56.7 & $4.36^{\star}$ & 2.6 & No & 1 & 1 & 1 & 3 \\
\hline $\begin{array}{l}\text { Heymsfield, } \\
2000^{\text {w28 }}\end{array}$ & Orlistat & $-0.95(0.35)$ & 35.8 & 44.1 & 1.59 & 4.8 & No & 1 & 1 & 0 & 2 \\
\hline XENDOS, $2004^{\mathrm{w} 37}$ & Orlistat & $-0.73(0.31)$ & 37.3 & 43.0 & 2.78 & 5.9 & Yes & 1 & 2 & 0 & 3 \\
\hline Fan, $2005^{\mathrm{w} 20}$ & $\begin{array}{l}\text { Jiangtang } \\
\text { bushen }\end{array}$ & $-1.14(1.15)$ & 25.5 & 56.0 & $0.90 *$ & 13.3 & No & 2 & 0 & 1 & 3 \\
\hline \multicolumn{12}{|c|}{ Studies not included in meta-analyses } \\
\hline EDIT, $2003^{\mathrm{w} 3}$ & $\begin{array}{l}\text { Acarbose and/ } \\
\text { or metformin }\end{array}$ & NA & 28.6 & 52.1 & NA & NA & NA & NA & NA & NA & NA \\
\hline JDPP, $2005^{\mathrm{w} 18}$ & $\begin{array}{l}\text { Diet and } \\
\text { exercise }\end{array}$ & NA & NA & NA & NA & NA & No & 1 & 0 & 0 & 1 \\
\hline Keen, $1973^{\text {w36 }}$ & $\begin{array}{l}\text { Tolbutamide } \\
\text { or diet }\end{array}$ & NA & 56.5 & NA & NA & NA & No & 1 & 1 & 0 & 2 \\
\hline Tripod, $2002^{\text {w34 }}$ & Troglitazone & NA & 37.0 & 43.0 & NA & 4.73 & Yes & 1 & 2 & 0 & 3 \\
\hline
\end{tabular}

Both=diet and exercise; NA=not available.

*Estimated from, or transformation of, original data.

HIncidence of type 2 diabetes per 100 person years in control group.

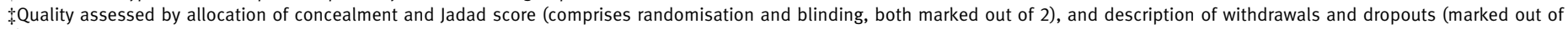
1). Total Jadad score was therefore out of 5.

reported 22 trials. A further study, the early diabetes intervention trial (EDIT), ${ }^{3}{ }^{\text {w } 4}$ was identified in a published review. ${ }^{1}$ We excluded six because the treatment allocation process had not been fully randomised ${ }^{\text {w5-w8 }}$ or the primary aim of the administered intervention was not to prevent type 2 diabetes. ${ }^{\mathrm{w} 9-\mathrm{w} 11} \mathrm{We}$ additionally assessed 10 foreign language papers, four Chinese, three Japanese, one Spanish, one Russian, and one German. Four were excluded as they were discussion papers rather than presenting original findings, ${ }^{\text {w12-w15 }}$ and one was excluded as although it met most of our inclusion criteria, type 2 diabetes was not a reported outcome. ${ }^{\text {w16 }}$ Of the five remaining relevant articles, two reported results from the Japanese diabetes prevention programme (JDPP) $)^{\mathrm{w} 17 \mathrm{w} 18}$ and three were results from three separate Chinese studies. ${ }^{\text {w19-w21 }}$

\section{Study characteristics}

Twenty one trials met the inclusion criteria for this systematic review, ${ }^{\text {w1 w2 w17-w39 }}$ and 17 of them, with 8084 participants, were included in the meta-analyses (tables 1-4). The trials were heterogeneous in terms of interventions, ethnicity, weight, and age. Because of the time period covered by the trials (1979-2006) several definitions for type 2 diabetes and impaired glucose tolerance had been used. ${ }^{18-22}$

Most definitions were similar: for type 2 diabetes they involve a plasma glucose reading of 
$\geq 11.1 \mathrm{mmol} / 1$ two hours after a $75 \mathrm{~g}$ glucose load and a fasting plasma glucose concentration of $\geq 7.8 \mathrm{mmol} / \mathrm{l}$. For impaired glucose tolerance the definition is 7.8$11.1 \mathrm{mmol} / \mathrm{l}$ two hours after a glucose load. In 1997 the American Diabetes Association revised the criteria $^{21}$ and the fasting plasma glucose concentration for diagnosis of type 2 diabetes was lowered from $\geq 7.8 \mathrm{mmol} / 1$ to $\geq 7.0 \mathrm{mmol} / 1$. The World Health Organization endorsed this reduction. Seven of the more recent studies in our review used this lower threshold in their definitions.

We did not included three relevant studies in the meta-analyses because they reported insufficient data and we could not obtain further data from the authors. ${ }^{\text {w3 }}$ w4 w17 w18 w36

\section{Quantitative data synthesis}

All the meta-analyses provided overwhelming evidence to support the benefit of interventions to prevent or delay type 2 diabetes. The pooled effect for all forms of lifestyle interventions gave a hazard ratio of 0.51 (95\% confidence interval 0.44 to $0.60, \mathrm{P}<0.001)$ (fig 2), indicating a relative $49 \%$ reduction in risk of developing diabetes. When we separately considered diet, exercise, and diet and exercise in combination they all showed a similar reduction in risk (hazard ratios $0.67,0.49$ to $0.92, \mathrm{P}=0.013 ; 0.49,0.32$ to 0.74 , $\mathrm{P}=0.001$; and $0.49,0.40$ to $0.59, \mathrm{P}<0.001$, respectively).

Both forms of pharmacological intervention-oral diabetes drugs and the anti-obesity drug-also showed a highly significant benefit of intervention compared with control (hazard ratios $0.70,0.62$ to 0.79 , $\mathrm{P}<0.001$, and $0.44,0.28$ to $0.69, \mathrm{P}<0.001$, respectively; fig 3). The one trial that assessed a herbal intervention had a favourable hazard ratio, although this was not significant $(0.32,0.03$ to $3.07, \mathrm{P}=0.323)$.

\section{Assessment and exploration of heterogeneity}

The $I^{2}$ value indicated that $0 \%$ of the variation in the meta-analyses of the anti-obesity drug and oral diabetes drugs and just $8.8 \%$ in the meta-analysis of lifestyle interventions was caused by between study heterogeneity. Table 5 shows the results of the metaregression analyses. For lifestyle intervention each one unit increase in the mean body mass index at baseline led to a decrease in the hazard ratio of $-7.3 \%$ $(-13.6$ to -0.9$), \mathrm{P}=0.029$. This provides evidence that as the average body mass index at baseline increased, the effectiveness of the lifestyle intervention also increased, meaning that lifestyle interventions were more effective in trials that recruited participants with higher body mass index values.

Baseline risk of type 2 diabetes varied greatly between trials, from 2.6 to 30.0 cases per 100 person years (table 4). Assessment of the data showed no indication of an interaction between the underlying baseline risk and the intervention effect, with only a small change in the log hazard ratio for a one unit increase in the log baseline risk, and the 95\% credible intervals containing the null value of zero; lifestyle interventions

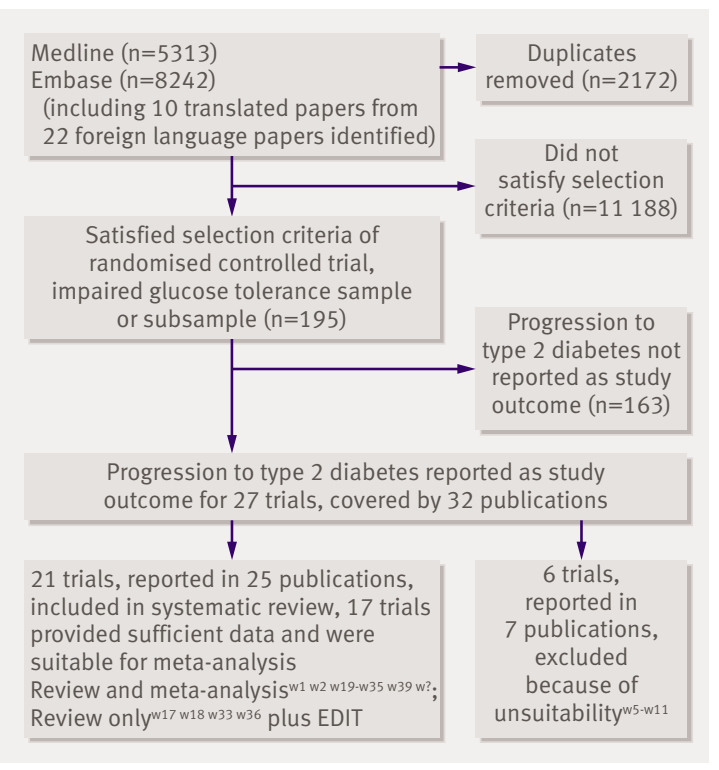

Fig 1 | Flow chart of literature search and meta-analysis

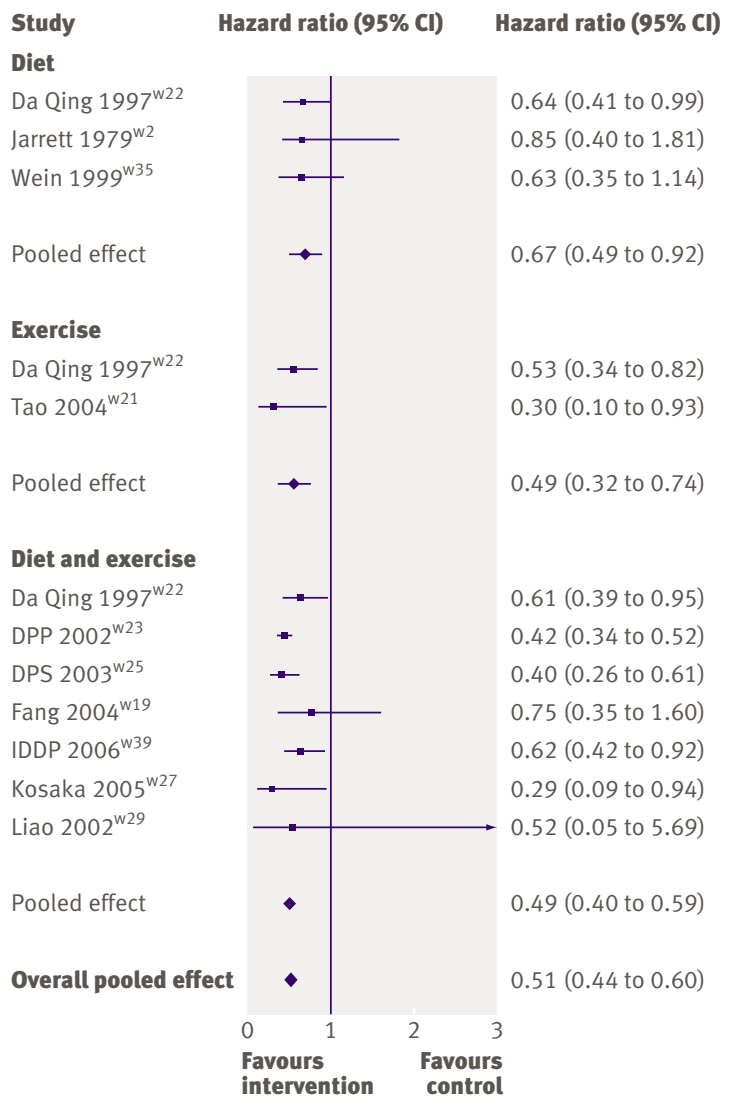

$\overline{\text { Fig } 2 \text { |Meta-analysis of effect of lifestyle interventions on risk of }}$ developing type 2 diabetes

$(0.08,95 \%$ credible interval -0.10 to 0.24$)$ and oral diabetes drugs $(-0.12,-0.70$ to 0.51$)$.

Removal of the trials that had used the newer diagnosis criteria for impaired glucose tolerance or type 2 diabetes had minimal effect on the results, with the pooled hazard ratio and 95\% confidence interval changing to 0.66 (0.46 to 0.94 ) for diabetes drugs and 0.55 


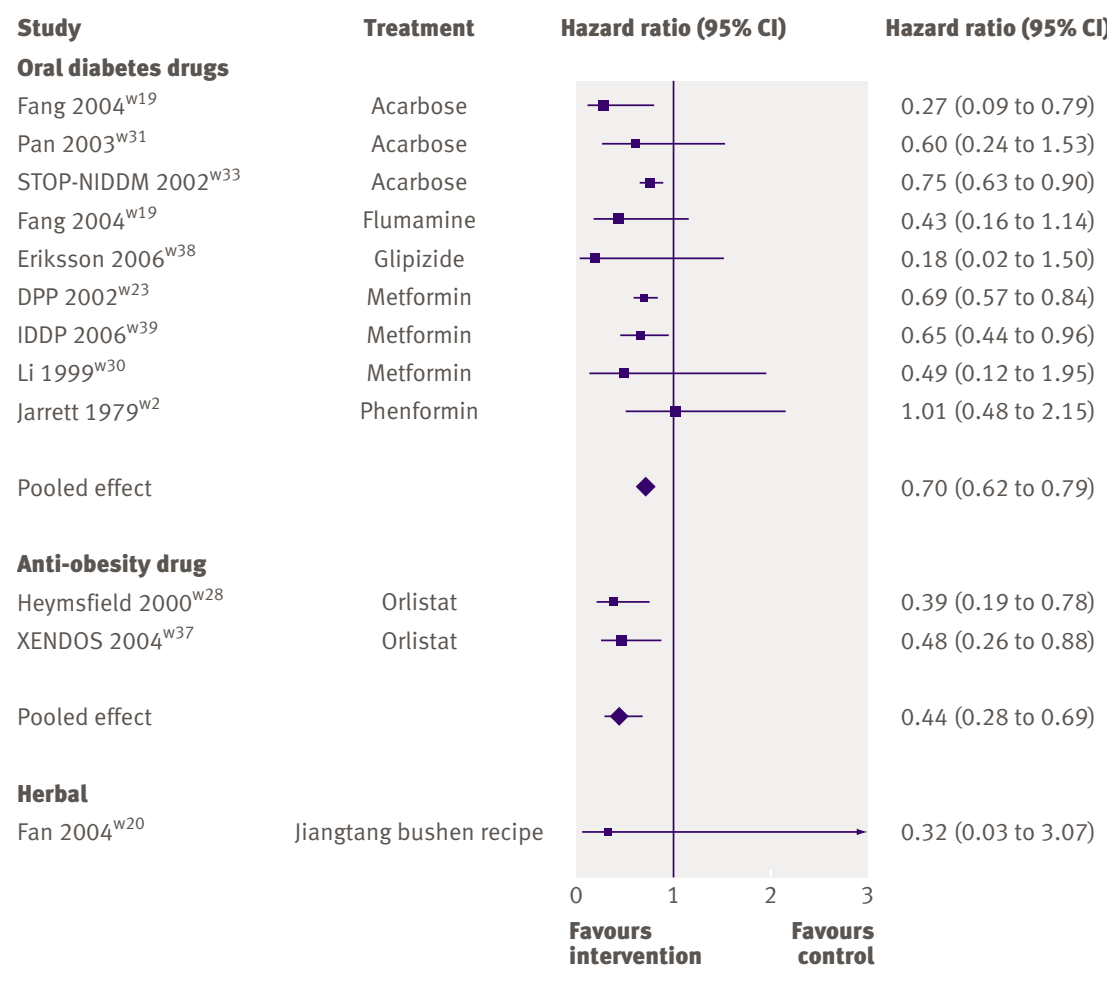

Fig $3 \mid$ Meta-analyses of effect of pharmacological and herbal interventions on risk of developing type 2 diabetes
(0.45 to 0.66$)$ for lifestyle interventions. The assessment of influence of an individual study showed that no single study greatly influenced the meta-analyses.

\section{Study quality and publication bias}

The three meta-analyses-lifestyle, diabetes drug, and anti-obesity drug-varied minimally when we omitted studies that had low Jadad scores or when we assessed the individual components of the Jadad score through sensitivity analyses. Concealment of allocation had potentially been carried out by only two studies, STOP-NIDDM ${ }^{\mathrm{w} 33}$ and XENDOS, ${ }^{\text {w37 }}$ although this was difficult to assess in many studies because of poor reporting. We did not identify any publication bias for the lifestyle meta-analysis (Begg's test $\mathrm{P}=0.945$ and

Table 5 | Results of meta-regression analyses of interventions to prevent or delay type 2 diabetes

\begin{tabular}{|c|c|c|c|}
\hline $\begin{array}{l}\text { Intervention and } \\
\text { covariate }\end{array}$ & $\begin{array}{l}\text { Coefficient* }(95 \% \\
\text { Cl) }\end{array}$ & $\begin{array}{c}\text { Percentage } \\
\text { change in hazard } \\
\text { ratio }(95 \% \mathrm{Cl})\end{array}$ & $P$ value \\
\hline \multicolumn{4}{|l|}{ Lifestyle } \\
\hline Mean BMI & $\begin{array}{c}-0.04(-0.08 \text { to } \\
-0.01)\end{array}$ & $-7.3(-13.6$ to -0.9$)$ & 0.029 \\
\hline Mean age (years) & $\begin{array}{c}-0.03(-0.07 \text { to } \\
0.01)\end{array}$ & $-3.8(-8.6$ to 1.0$)$ & 0.106 \\
\hline Follow-up (years) & $0.15(-0.04$ to 0.35$)$ & $9.5(-3.3$ to 30.0$)$ & 0.108 \\
\hline \multicolumn{4}{|c|}{ Oral diabetes drugs } \\
\hline Mean BMI & $0.02(-0.03$ to 0.07$)$ & $1.9(-4.1$ to 7.8$)$ & 0.482 \\
\hline Mean age (years) & $0.03(-0.02$ to 0.08$)$ & $1.5(-1.4$ to 4.4$)$ & 0.257 \\
\hline Follow-up (years) & $0.08(-0.17$ to 0.33$)$ & $13.1(-30.0$ to 56.3$)$ & 0.495 \\
\hline
\end{tabular}

Egger's test $\mathrm{P}=0.340)$. For meta-analysis of diabetes drugs the Begg's test result was significant $(\mathrm{P}=0.012)$ and the Egger's test result, although not significant, still indicated a problem may be present $(\mathrm{P}=0.058)$.

\section{Assessment of absolute effect of interventions}

Combining the baseline hazards in the control arms of all 17 trials gave a cumulative incidence of diabetes over five years of $37.1 \%$, which is in line with previously reported estimates. ${ }^{2324} \mathrm{With}$ the pooled hazard ratios from the meta-analyses, the absolute difference in incidence of diabetes, in terms of percentage points, would be -15.8 (95\% credible interval -19.8 to -11.9$)$ for lifestyle intervention, $-9.3(-12.4$ to -6.7$)$ for oral diabetes drugs, $-18.4(-24.6$ to -13.1$)$ for orlistat, and -22.7 ( -37.9 to 11.7 ) for the jiangtang bushen. We used these figures to calculate numbers needed to treat (NNT), where NNTB implies benefit-that is, the number needed to be treated with the intervention compared with the control treatment to prevent or delay one case of diabetes-and NNTH implies harming effect of the intervention-that is, the number needed to be treated by the control treatment compared with intervention to prevent or delay one case of diabetes..$^{25}$ The numbers needed to treat were $6.4(95 \%$ credible interval NNTB 5.0 to NNTB 8.4) for lifestyle, 10.8 (NNTB 8.1 to NNTB 15.0) for oral anti-diabetic drugs, 5.4 (NNTB 4.1 to NNTB 7.6) for orlistat, and 4.0 (NNTH 16.9 to NNTB 24.8) for jiangtang bushen recipe.

\section{Adverse events}

Most adverse events possibly related to the intervention drugs were gastrointestinal or, in the case of troglitazone, a decline in liver function. Although adverse events varied widely between trials, all were more common in the intervention than in the placebo groups (table 6).

\section{Studies not included in the meta-analyses}

We omitted the Tripod ${ }^{\text {w34 }}$ study and the arm of the diabetes prevention programme (DPP) trial ${ }^{\mathrm{w} 1}$ that assessed troglitazone from the meta-analyses as troglitazone is no longer a viable intervention for delaying diabetes because of safety concerns. Both trials showed a significant reduction in the development of diabetes with troglitazone. Three additional trials fitted the inclusion criteria for this systematic review but provided insufficient data for inclusion in the meta-analy-

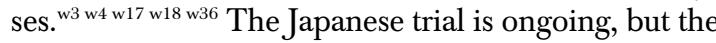
preliminary results that have been published report a halving of risk of diabetes in those who received advice on diet and exercise. ${ }^{\text {w17w18 }}$ The results of the early diabetes intervention trial ${ }^{\mathrm{w} 3 \mathrm{w} 4}$ and research by Keen et $\mathrm{al}^{\mathrm{w} 36}$ were less conclusive than the meta-analyses reported here. The early diabetes intervention trial found the relative risk of type 2 diabetes was significantly reduced by acarbose $(0.66, \mathrm{P}=0.046)$ but not metformin $(1.09, \mathrm{P}=0.70)$ or combination therapy $(0.72, \mathrm{P}=0.27) .{ }^{\mathrm{w} 3} \mathrm{w} 4 \mathrm{Keen}$ et al concluded there was no 
evidence that either tolbutamide or a carbohydrate restricted diet reduced incidence of diabetes. ${ }^{\text {w36 }}$

\section{Studies excluded from the review}

We excluded six studies identified by the search strategy. Of the three with inadequate randomisation, Sartor et al assessed the effects of tolbutamide and diet, and their results showed $29 \%$ of controls, 13\% on diet alone, and none on a maintaining diet with tolbutamide developed diabetes. ${ }^{\text {w5 }}$ The Malmo trial compared a diet and exercise programme with standard advice and found a relative risk reduction of 0.37 (95\% confidence interval, 0.20 to 0.68$),{ }^{\text {w7 }}$ and Swinburn et al compared a reduced fat diet with standard advice and found a significantly lower proportion of participants had diabetes at one year in the intervention group $(47 \% v 67 \%, \mathrm{P}<0.05) .{ }^{\mathrm{w} 6}$ Therefore all three of these trials reported similar results to the included trials. Of the three trials that looked at prevention of diabetes as post hoc analyses, two assessed angiotensin converting enzyme inhibitors (captopril and ramipril) ${ }^{\mathrm{w} 9} \mathrm{w} 11$ and one looked at bezafibrate, ${ }^{\text {w10 }}$ which lowers concentrations of triglycerides and raises concentrations of high density lipoprotein cholesterol. The drugs assessed in these trials are different to those in our review and none of these trials reported results solely for people with impaired glucose tolerance so their results are not directly comparable with ours.

Table 6 | Reported adverse events possibly attributable to pharmacological interventions to prevent or delay type 2 diabetes. Numbers are percentages except where indicated

\begin{tabular}{|c|c|c|c|}
\hline $\begin{array}{l}\text { Active } \\
\text { intervention and } \\
\text { trial }\end{array}$ & Event & $\begin{array}{l}\text { Inter- } \\
\text { vention } \\
\text { group }\end{array}$ & $\begin{array}{l}\text { Place- } \\
\text { bo } \\
\text { group }\end{array}$ \\
\hline \multicolumn{4}{|l|}{ Acarbose } \\
\hline Fang, $2004^{\mathrm{w} 19}$ & Gastrointestinal side effects & 8.0 & 0.0 \\
\hline Pan, $2003^{\text {w31 }}$ & Gastrointestinal side effects & 35.7 & 18.2 \\
\hline $\begin{array}{l}\text { STOP-NIDDM, } \\
2002^{\mathrm{w} 33}\end{array}$ & Gastrointestinal side effects & 13.0 & 2.5 \\
\hline \multicolumn{4}{|l|}{ Flumamine } \\
\hline Fang, $2004^{\text {w19 }}$ & Gastrointestinal side effects & 6.3 & 0.0 \\
\hline \multicolumn{4}{|l|}{ Glipizide } \\
\hline $\begin{array}{l}\text { Eriksson, } \\
2006^{\text {w38 }}\end{array}$ & Hypoglycaemic symptoms & 41.0 & 32.0 \\
\hline \multicolumn{4}{|l|}{ Troglitazone } \\
\hline \multirow[t]{2}{*}{ DPP, $2005^{\mathrm{w} 1}$} & Liver function test $\geq 3$ & 4.3 & 3.6 \\
\hline & Liver function test $\geq 10$ & 1.2 & 0.2 \\
\hline \multicolumn{4}{|l|}{ Metformin } \\
\hline DPP, $2002^{\text {w23 }}$ & Gastrointestinal symptoms & $77.8^{\star}$ & $30.7^{\star}$ \\
\hline \multirow[t]{2}{*}{ IDDP, $2004^{\mathrm{w} 39}$} & Hypoglycaemia & 8.4 & 0.0 \\
\hline & Gastrointestinal symptoms & 1.9 & 0.0 \\
\hline $\mathrm{Li}, 1999^{\mathrm{w} 30}$ & Gastrointestinal side effects & 4.4 & 0.0 \\
\hline \multicolumn{4}{|l|}{ Orlistat } \\
\hline \multirow[t]{3}{*}{ XENDOS, $2004^{\text {w37 }}$} & $\begin{array}{l}\text { At least one gastrointestinal } \\
\text { event in } 1 \text { st year }\end{array}$ & 91.0 & 65.0 \\
\hline & $\begin{array}{l}\text { At least one gastrointestinal } \\
\text { event in } 4 \text { th year }\end{array}$ & 36.0 & 23.0 \\
\hline & $\begin{array}{l}\text { Withdrawals because of } \\
\text { adverse events }\end{array}$ & 4.0 & 8.0 \\
\hline
\end{tabular}

*Number of events per 100 person years.
Tenenbaum et al concluded that bezafibrate reduces the incidence and delays the onset of type 2 diabetes in patients with impaired fasting glucose (hazard ratio $0.70,95 \%$ confidence interval 0.49 to 0.99$).{ }^{\text {w10 }}$ In a population with primary hypertension one study found that in patients with hypertension captopril was associated with a lower risk of diabetes than conventional treatment with diuretics or $\beta$ blockers, or both $(0.82,0.70$ to $0.96, \mathrm{P}=0.014)$, ${ }^{\text {w9 }}$ and in individuals with vascular disease the HOPE trial concluded that ramipril was associated with a lower risk of diabetes compared with placebo (relative risk $0.66,0.51$ to $0.85, \mathrm{P}<0.001){ }^{\text {w11 }}$

\section{DISCUSSION}

Our meta-analyses show that intervention can reduce the risk of type 2 diabetes in people with impaired glucose tolerance, and lifestyle interventions seem to be at least as effective as pharmacological interventions. The increase in obesity and decrease in physical activity in Westernised societies are strongly linked with the increase in the prevalence and incidence of type 2 diabetes. ${ }^{1}$ Lifestyle interventions, which aim to reduce obesity and increase physical activity, help to directly address these risk factors. In 2000 an estimated 171 million people in the world had diabetes, and the numbers are projected to double by $2030 .^{26}$ Interventions to prevent type 2 diabetes will therefore have an important role in future health policies.

Regarding the long term impact of interventions, the diabetes prevention programme reported progression to type 2 diabetes after withdrawal from troglitazone and metformin. ${ }^{\text {w127 }}$ Results showed the treatment effect was not sustained after treatment stopped. It is therefore important that longer term follow-up is assessed and also that patients are comfortable during treatment. Even minor adverse events, such as the gastrointestinal adverse effects summarised here, take on greater importance if interventions have to be taken for life. Generally we can assume that lifestyle interventions incur fewer and less serious side effects than drug treatment, but, as with the pharmacological interventions, their effect may not be permanent and advice on diet and exercise may need to be reinforced on a regular basis. Additionally, although compliance was high in these trials, we still do not know whether compliance could be maintained outside of a trial setting.

Most of the hazard ratios and incidence rate ratios included in the meta-analyses were unadjusted, except those used for Wein et al, ${ }^{\text {w35 }}$ STOP-NIDDM, ${ }^{\text {w33 }}$ and Indian diabetes prevention programme (IDDP). ${ }^{\text {w39 }} \mathrm{As}$ trial arms were similar at baseline for unadjusted and adjusted characteristics, it is unlikely that adjustment introduced any inconsistency into the meta-analyses.

From the meta-regression results it seems that lifestyle interventions may have a greater impact the higher the mean baseline body mass index. Use of study level data, however, can lead to problems of aggregation bias, where there seems to be an association when in fact one does not exist at an individual 


\section{WHAT IS ALREADY KNOWN ON THIS TOPIC}

Incidence and prevalence of type 2 diabetes is rapidly increasing in Westernised societies

Type 2 diabetes can reduce life expectancy by up to 15 years and accounts for around $5 \%$ of NHS resources

People with impaired glucose tolerance are at greater risk of developing type 2 diabetes

Lifestyle and pharmacological interventions may be effective at delaying or preventing type 2 diabetes

\section{WHAT THIS STUDY ADDS}

Interventions can halve the risk of type 2 diabetes in people with impaired glucose tolerance Lifestyle interventions seem to be at least as effective as pharmacological interventions

level. ${ }^{14}$ To conduct a more conclusive assessment we would need data on individuals.

There was great diversity in study quality, with the lifestyle trials generally scoring lower on the Jadad score, because blinding of treatment was not possible. The trial of Heymsfield et al ${ }^{\mathrm{w} 28}$ combined data from three randomised controlled trials on weight loss. Though it was not a true single study we treated it as such for the purposes of these analyses as results were not available for each trial individually. All three trials were almost identical in their design and had not been individually powered to assess incidence of type 2 diabetes as an outcome.

Since we carried out our literature search a further relevant trial has been published-the diabetes reduction assessment with ramipril and rosiglitazone medication (DREAM) trial. ${ }^{2829}$ Unfortunately we could not include it as we were unable to obtain relevant data. This trial reported only combined results for individuals with either impaired glucose tolerance or impaired fasting glucose so it is not directly comparable with our meta-analyses here, but in summary they found the ACE inhibitor ramipril did not significantly reduce the incidence of diabetes (hazard ratio $0.91,0.80$ to 1.03 ) but rosiglitazone, an oral diabetes drug, did $(0.38,0.33$ to 0.44$)$. Heneghan et al have recently expressed concern over the rate of cardiovascular events in the rosiglitazone group. ${ }^{30}$

\section{Conclusions}

While we have shown the clinical effectiveness of both pharmacological and lifestyle interventions in significantly reducing the risk of developing type 2 diabetes in people with impaired glucose tolerance, several issues remain. Determining the best approach to intervention, be it pharmacological or lifestyle, depends not just on their performance in trial settings but on issues not yet resolved. For pharmacological interventions adverse effects need to be fully understood to enable potential harms and benefits to be assessed. Also should what is fundamentally a lifestyle issue really be treated with a lifelong course of medication? As compliance is the key to the success of lifestyle interventions, strategies to assist compliance need to be carefully thought through and implemented.

Finally, the evidence meta-analysed here is on patients already identified as having impaired glucose tolerance. The overall effectiveness and cost effectiveness of a policy of prevention or delay of diabetes must consider how different identification and screening strategies would affect the overall evaluation of such policies.

We thank Vanessa Beck, Santiago Moreno, Julia Chernova, Ki-Shing Victor Miu, and Noriaka Sawa, who helped with translations.

Contributors: CLG is guarantor of the paper. She performed the literature search, extracted and analysed the data, and wrote the first draft of the article. All other authors contributed to the writing of the paper, and gave advice and input at all stages of the study. Additionally KRA, PCL, and KK also assisted with data extraction and analysis. The initial idea for this review came from KRA and KK.

Funding: CLG is funded jointly by the UK Medical Research Council and the Economic and Social Research Council under an interdisciplinary postgraduate research studentship in the social and medical sciences. NJC is funded by a Medical Research Council training fellowship in health services research. Competing interests: KK has received sponsorship for attending conferences and small honorariums from pharmaceutical companies that manufacture drugs for hypoglycaemia and anti-obesity drugs. Ethical approval: Not required.

1 Davies MJ, Tringham JR, Troughton J, Khunti KK. Prevention of type 2 diabetes mellitus. A review of the evidence and its application in a UK setting. Diabet Med 2004;21:403-14.

2 Department of Health. National service framework for diabetes: standards. London: DoH, 2001.

3 Edelstein SL, Knowler WC, Bain RP. Predictors of progression from impaired glucose tolerance to NIDDM: an analysis of six prospective studies. Diabetes 1997;46:701-10.

4 Angelo JB, Huang J, Carden D. Diabetes prevention: a review of current literature. Adv Stud Med 2005;5:250-9.

5 Anderson DC Jr. Pharmacologic prevention or delay of type 2 diabetes mellitus. Ann Pharmacother 2005;39:102-9.

6 Norris SL, Zhang X, Avenell A, Gregg E, Bowman B, Schmid CH, et al. Long-term effectiveness of weight-loss interventions in adults with pre-diabetes: a review. Am / Prev Med 2005;28:126-39.

7 Norris SL, Zhang X, Avenell A, Gregg E, Schmid CH, Lau J. Long-term non-pharmacological weight loss interventions for adults with prediabetes. Cochrane Database Syst Rev 2005;(2):CD005270.

8 Prisant LM. Preventing type II diabetes mellitus. J Clin Pharmacol 2004;44:406-13.

9 Padwal R, Laupacis A. Antihypertensive therapy and incidence of type 2 diabetes: a systematic review. Diabetes Care 2004;27:247-55.

10 Higgins JPT, Green S. Cochrane handbook for systematic reviews of interventions 4.2.5. Chichester: John Wiley, 2005.

11 Jadad AR, Moore AR, Carroll D, Jenkinson C, Reynolds DJM, Gavaghan DJ, et al. Assessing the quality of reports of randomised clinical trials: is blinding necessary? Control Clin Trials 1996;17:1-12.

12 Parmar MKB, Torri V, Stewart L. Extracting summary statistics to perform meta-analyses of the published literature for survival endpoints. Stat Med 1998;17:2815-34.

13 Clayton D, Hills M. Statistical models in epidemiology. Oxford: Oxford University Press, 1993.

14 Sutton AJ, Abrams KR, Jones DR, Sheldon TA, Song F. Methods for meta-analysis in medical research. Chichester: John Wiley, 2000.

15 Higgins JPT, Thompson SG, Deeks JJ, Altman DG. Measuring inconsistency in meta-analyses. BMJ 2003;327:557-60.

16 Sharp SJ, Thompson SG. Analysing the relationship between treatment effect and underlying risk in meta-analysis: comparison and development of approaches. Stat Med 2000;19:3251-74.

17 Spiegelhalter DJ, Thomas A, Best N. WinBUGS user manual. Cambridge: MRC Biostatistics Unit, 2003. www.mrc-bsu.cam.ac.uk/ bugs/winbugs/manual14.pdf

18 World Health Organization Expert Committee. Prevention of diabetes mellitus. World Health Organ Tech Rep Ser 1994;844:1-100.

19 World Health Organization Expert Committee. Diabetes mellitus, second report. World Health Organ Tech Rep Ser 1980;646:1-80.

20 WHO Study Group. Diabetes mellitus. World Health Organ Tech Rep Ser 1985;727:1-113.

21 American Diabetes Association. Report of the expert committee on the diagnosis and classification of diabetes mellitus. Diabetes Care 1997;23:1619-29.

22 Alberti KG, Zimmet PZ. Definition, diagnosis and classification of diabetes mellitus and its complications. Diagnosis and classification of diabetes mellitus: provisional report of a WHO consultation. Diabet Med 1998;15:539-53. 
23 De Vegt F, Dekker JM, Jager A, Hienkens E, Kostense PJ, Stehouwer CD, et al. Relation of impaired fasting and postload glucose with incident type 2 diabetes in a Dutch population: the Hoorn study. JAMA 2001;285:2109-13.

24 Edelstein SL, Knowler WC, Bain RP, Andres R, Barrett-Connor EL, Dowse GK, et al. Predictors of progression from impaired glucose tolerance to NIDDM: an analysis of six prospective studies. Diabetes 1997;46:701-10.

25 Altman DG. Confidence intervals for the number needed to treat. BM] 1998;317:1309-12.

26 Wild S, Roglic G, Green A, Sicree R, King H. Global prevalence of diabetes: estimates for the year 2000 and projections for 2030. Diabetes Care 2004;27:1047-53.
27 Diabetes Prevention Program Research Group. Effects of withdrawa from metformin on the development of diabetes in the diabetes prevention program. Diabetes Care 2003;26:977-80.

28 Dream Trial Investigators. Effect of ramipril on the incidence of diabetes. N Engl J Med 2006;355:1608-10.

29 Dream Trial Investigators. Effect of rosiglitazone on the frequency of diabetes in patients with impaired glucose tolerance or impaired fasting glucose: a randomised controlled trial. Lancet 2006;368:1096-105.

30 Heneghan C, Thompson M, Perera R. Prevention of diabetes. BMJ 2006;333:764-5.

Accepted: 28 November 2006 